\title{
Lærende relationer - Coaching og undervisning
}

\author{
Monika Janfelt, lektor, fil.dr., Institut for Historie, Kultur og Samfundsbeskrivelse, \\ Syddansk Universitet
}

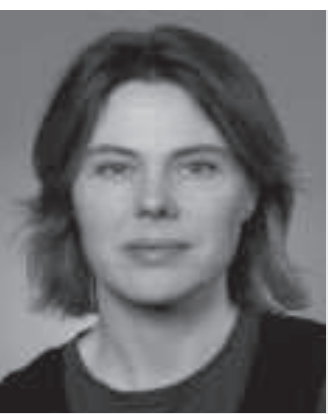

Monika Janfelt er fil.dr. og lektor i dansk og nordisk historie i det 20. århundrede ved Institut for Historie, Kultur og Samfundsbeskrivelse ved Syddansk Universitet. Hun beskæftiger sig med social- og kulturhistoriske emner, primært inden for barndomshistorie, nordisk samarbejde og tekstilhistorie. Hun er også uddannet som systemisk coach og coacher på SDU og i andre sammenhænge.

Coaching kan med fordel bruges i forskellige universitetssammenhoenge, ikke kun som individuel coaching af studerende omkring opgaveskrivning, eksamen og andre studenterrelaterede temaer, men også $i$ forbindelse med traditionel undervisning og undervisernes padagogiske udvikling. Coaching handler om laring, og tanken om det ressourcefyldte menneske står helt centralt. Derfor er både tankerne bagved og de praktiske varktojer $i$ coaching relevant for det universitetspadagogiske felt.

Jeg vil $i$ denne artikel beskrive et par coachingveerktojer, og hvordan jeg har provet at implementere dem i forbindelse med et undervisningsforløb med forsteårsstuderende på historie ved SDU. Jeg vil indledningsvis sige noget alment om, hvad coaching er, for derved at gore det mere klart, $i$ hvilken sammenhang de enkelte tilgange og det beskrevne undervisningsforløb skal ses. Ability Spotting og Appreciative Inquiry (AI) er de to coachende tilgange, jeg bragte $i$ spil $i$ et konkret fremlaggelsesforløb, som jeg afslutningsvis beskriver $i$ denne artikel.

\section{Hvad er coaching?}

Coaching er et felt, som er kommet stærkt frem de seneste 15-20 år. Coaching kan være mange ting og jo mere populært et fænomen bliver, i desto flere sammenhænge og betydninger bliver det brugt, mere eller mindre velfunderet. Således også med begrebet coaching. Det bliver ikke mindre klart af, at der dertil findes flere coaching-retninger med forskellige ud- gangspunkter og traditioner. Jeg arbejder ud fra en systemisk tilgang, med fokus på organisationer og lærende relationer, og hvor systemteori danner den teoretiske baggrund for mit arbejde. Kommunikation mellem systemer står her centralt.Vigtigt er også, at personen og opgaven/problemet ses i konteksten, i sammenhæng og som relationer i organisationer. Det konstruktivistiske perspektiv står centralt i den systemiske tilgang, hvilket eksempelvis indebærer, at der arbejdes med metaforer, og hvordan den coachede ser på sin omverden.

Coaching er en samtaleform, der er med til at skabe retning. Hovedtanken er, at den, der ønsker coaching, selv kommer med et problem, noget personen vil udvikle eller opnå i fremtiden. Omdrejningspunktet er hele vejen igennem fokuspersonen, dvs. den der ønsker coaching, ud fra tanken om, at det er personen selv, der sidder inde med løsningerne og svarene. Coachen stiller spørgsmål, lytter, fremhæver positive erfaringer eller arbejder med andre samtaleteknikker - såsom eksempelvis den anerkendende tilgang - for at åbne op for nye måder at anskue tingene på og løfte personens evner, ressourcer og egne løsningsforslag frem. En coach er i høj grad en sparringspartner og en, der målretter processen hen imod større bevidsthed eller konkrete løsninger. I coaching er spørgsmål og feedback meget vigtige, hele tiden med konstruktiv fokus på personens evner og de læringspotentialer, der ligger i personens egne erfaringer.

Der er en teknisk og metodisk side ved coaching omkring spørgsmålstyper, fremgangsmåder, rækkefølger og modeller osv., der kan følges. God coaching er givetvis meget mere end det. Det er bl.a. en ledelsesdisciplin, en organisationsfilosofi og en lærende relation. Som undervisere arbejder vi i høj grad med læringsprocesser og virker som ledere for den enkelte studerende og for grupper, derfor er coaching både brugbar og frugtbar i pædagogiske sammenhænge.

\section{Hvorfor coaching?}

Man hører af og til at coaching er noget poppet og noget, som viser, at man er med på noderne. Derfor 
er det på sin plads at spørge sig, hvorfor coaching skal tages seriøst. Man kan sige, at i en globaliseret verden og $i$ det moderne videnssamfund er evnen til at håndtere sine egne lærings- og reflektionsprocesser, både som individ men også som organisation, livsafgørende og et 'must' for at klare sig godt. Lærende relationer handler i høj grad om at styrke bevidstheden om sig selv og derved sin sociale og emotionelle intelligens, som bl.a. Daniel Goleman og Howard Gardner taler om. Coaching som en samtaleform, hvor vi kan lære noget, er som sådan ikke ny. Mange af de elementer, vi kender i coaching, er brugt for. Det nye er, at de er blevet formaliserede pga. vores behov for at navigere i vores individualiserede samfund, men også ud fra effektivitetshensyn og ændrede arbejdsforhold. Behovet og lysten til at lære er heller ikke ny, men de lærende relationer har fået ny vind i sejlene, måske i kraft af de drivkræfter i vores samfund, der får os til at stræbe efter ikke bare at lære nyt, men hele tiden at tænke $i$ nye baner. Vi har som sådan ikke tid til at dvæle ved tingene i særlig lang tid, og derfor har vi også fået et behov for nogle systematiske værktøjer til at målrette beslutnings- og læreprocesser. Samtidigt er coaching en proces - og processer er som sådan tidskrævende og hele tiden i vækst. Kravet om evig forandring og selvrefleksion har også sine skyggesider, som jeg ikke vil gå ind på her. Coaching er heller ikke en velegnet metode $\mathrm{i}$ alle situationer, såsom når man har brug for faktuel rådgivning og viden for at kunne løse et problem. Coaching er heller ikke den bedste løsning, når det handler om spørgsmål af dybere personlig art. I de tilfælde er den, der søger vejledning, bedre hjulpet af en præst eller psykolog.

\section{Hvad kan coaching bruges til på universiteterne?}

Som tidligere nævnt handler coaching om problemløsning, refleksion, bevidstgørelse og derved udvikling af evner og potentialer. Alt det, vi til dagligt arbejder med på landets universiteter. Jeg vil i det følgende beskrive et fremlæggelsesforløb, hvor jeg prøvede at give feedback til mine studerende ud fra en coachende tankegang, og hvor jeg brugte to bestemte fremgangsmåder inden for coaching. Den ene var Ability Spotting - dvs. det at fremhæve og genfortælle den studerendes evner og talenter og derved "spotte« de evner, som den studerende demonstrerede i den pågældende situation. Dertil hentede jeg inspiration fra Appreciative Inquiry - den anerkendende samtale, som bliver brugt i mange sammenhænge, men som også kan bidrage til god undervisning. Den bygger på en positiv grundtænkning med fokus på ressourcer, kompetencer, muligheder og det, der lykkedes. Dvs. det, der ikke lykkes, bringes ikke i spil, mens det, der går godt, bliver vist interesse og udfoldet.

Selve fremlæggelsesforløbet indgik i områdeunder- visning på første semester. Jeg stillede de studerende et spørgsmål i et bestemt historisk tema, som de fik tid til at forberede hjemme, hvorefter de indleverede en synopsis, der også skulle godkendes af mig. Derefter holdt vi seminar over to dage, hvor de hver især holdt et oplæg over deres tema af 10-15 minutters varighed. Den mundtlige fremlæggelse var en forudsætning for at gå op til mundtlig eksamen i januar og var derfor obligatorisk, men uden karaktergivning. Efter hver fremlæggelse var der tid til spørgsmål og refleksioner fra de andre studerende, hvorefter jeg afsluttede med en mere udførlig feedback på den studerendes oplæg med den samlede gruppe som tilhørere. Dette var min fremgangsmåde for hver fremlæggelse.

I min feedback brugte jeg de to ovennævnte coachingmetoder. Konkret foregik det sådan, at jeg genfortalte, hvad den studerende havde fremlagt fagligt, og hvordan fremlæggelsen var struktureret, dvs. på en deskriptiv måde uden bedømmelse. Men jeg havde samtidig fokus på det, der lykkedes og gik godt, og undlod helt bevidst enhver form for negativ kritik eller at fremhæve svagheder og mangler. Al opmærksomhed lagdes på den enkeltes evner og styrkesider gennem brugen af Ability Spotting. Jeg var specifik og konkret i min udtalelse, men var samtidigt omhyggelig med, at det foregik på et højt abstraktionsniveau, og at jeg på en anerkendende måde (AI) beskrev den enkelte studerendes præstation.

Mine kommentarer handlede om mange ting, bl.a. det faglige indhold, vigtige problemstillinger, den fysiske fremtræden, såsom stemme, kropsholdning og kontakt til publikum, eller om personen var glad og energisk, og hvilke positive effekter det har på tilhørerne. Jeg beskrev den studerendes analytiske evne ud fra konkrete detaljer i oplægget eller refererede, hvordan den studerende havde bygget sin argumentation op, eller hvordan vigtige holdepunkter tydeliggjordes. Jeg beskrev bl.a., hvad den enkelte gjorde, og hvordan personen havde vægtet sit emne eller valgt at forklare problemstillingen - uden at bedømme om dette eller hint var mangelfuldt eller forkert, eller om der også var andre forklaringsmodeller, der kunne diskuteres. I den fælles afsluttende evaluerende diskussion om seminarforløbet forklarede jeg dem, at i en sædvanlig mundtlig eksamenssituation ville det rent faktuelle indhold vægte mere.

\section{Mit ærinde}

Hvad var så mit ærinde, og hvad fik de studerende forhåbentlig med sig? Da det var en situation uden karaktergivning, kunne jeg tillade mig helt at se bort fra at rette og påpege manglerne - $\mathrm{i}$ et mere traditionelt fremlæggelsesforløb ville fejlfortolkningerne, haltende sammenhængsforståelse og faktuelle bommerter være blevet taget op. Jeg vil dog påpege, at man som under- 
viser ikke altid skal undlade at rette faktuelle fejl - man kan også komme langt med at analysere, hvad der fungerede mindre godt, og diskutere, hvordan man i stedet kunne have grebet det an - men hver ting til sin tid. En anden årsag var, at der var publikum på. Anerkendende konstruktiv feedback forstærkes, når der er tilhørere. Det gælder også for negativ kritik. Tanken var, at de studerende skulle få øje på alt det, de havde tilegnet sig efter kort tid på SDU og historiestudiet og samtidigt gøre dem bevidste om egne evner og potentialer. Den anerkendende tilgang og at beskrive begivenheder og fokusere på det, der lykkes, handler ikke om ros og klap på ryggen om, hvor godt det hele gik. De læringsressourcer, som er på spil i feedback, som kun handler om ros i største almindelighed, er begrænsede.

Mit ærinde var at skabe et godt fællesskab og placere de studerende i en situation, hvor de blev en del af det fællesskab, som fortolker og skaber historie. Jeg mente, at det var vigtigt at gribe situationen an, sådan at de kunne mærke deres kunnen og fik vist deres kompetencer i en faglig sammenhæng. Tanken var også, at de skulle lære af hinanden, og at de kunne se, at man kan lave et godt mundtligt oplæg på mange forskellige måder. Den konstruktive feedback var også tænkt som noget, de kunne tage med sig i deres videre færd.

Mit formål var, at de efter de to dage, foruden den faglige historiske viden de havde tilegnet sig, også skulle gå derfra med større indsigt i, hvad de kan, og hvad de kan lære. At blive historiker er en proces. Min forhåbning var, at disse to dage havde bidraget til denne proces på en konstruktiv måde.

En effekt af at spotte evner og anerkende en persons indsats kunne ses allerede under den anden seminardag. Der kunne jeg se og høre, at den stil, jeg havde lagt, når jeg gav feedback, havde influeret på gruppens indbyrdes samspil. Deres spørgsmål og kommentarer til hinandens oplæg i de efterfølgende diskussioner afspejlede, at de selv var begyndt at se deres medstuderendes faglige styrker og potentialer, og de udtrykte det på en anerkendende måde.

De studerendes reaktioner på måden, oplægsseminarerne var blevet afholdt på, var positive. De var meget opmærksomme på det, jeg havde at sige om deres fremlæggelser, og deres kommentarer bagefter lod mig forstå, at jeg havde opnået det, jeg havde villet: At de skulle gå derfra med nye indsigter omkring sig selv som historikere og om, hvordan forskellige tilgange virker.

\section{Coaching og undervisning}

Coachende arbejdsmetoder, såsom AI og Ability Spotting, mener jeg kan fremme læring og få den studerende eller den, der underviser, til at finde ud af, hvordan de henholdsvis lærer bedst og bedst lærer fra sig, og er således nyttige pædagogiske veje for at fremme nysgerrigheden. Ovenstående eksempel viser, at coaching ikke kun skal og kan bruges i form af individuelle samtaler, men at elementer inden for coaching også kan bruges til at prøve nye veje $\mathrm{i}$ almindelige undervisningssituationer. Coaching er et personligt udviklingsredskab, men fordi vi i vores undervisning udvikler de studerendes personlighed i relation til en bestemt faglighed, mener jeg, at undervisere med fordel kan trække på coaching i mange arbejdssituationer.

Som eksemplet fra min undervisning viste, bidrager coachende arbejdsmetoder til, at de studerende hurtigere finder deres læringsstil og styrkesider som, i dette tilfælde, historikere. For mit eget vedkommende har coaching skærpet mit blik for undervisningens processuelle sider. Den coachende tankegang har bidraget til at øge min bevidsthed over min egen rolle som underviser, hvad jeg, rent læringsmæssigt, ønsker opnå samt øget min forståelse for forskellige didaktiske metoders læringspotentiale. Coachende tankegange og metoder fremmer ikke kun de studerendes læring, men kan således også fremme undervisernes egne pædagogiske refleksioner og mål med undervisningen.

\section{Litteratur og reference}

Artiklen er skrevet på baggrund af den coach-certificeringsuddannelse, jeg har gennemgået ved Attractor - Institut for systemisk ledelse, kommunikation og intervention $\mathrm{ApS}$, samt mine praktiske erfaringer som coach og underviser ved SDU. Der er skrevet en del om coaching; her kan jeg henvise til et par værker.

Gardner, H. (2005). Changing minds - sådan påvirkes holdninger og meninger, København: Børsen. Oversættelse.

Gardner, H. (2007). Fem tanker for fremtiden, København: Børsen. Oversættelse.

Gjerde, S. (2006). Coaching - hvad, hvorfor, hvordan, København: Forlaget Samfundslitteratur.

Oversættelse.

Goleman, D. (2007). Folelsernes intelligens, Valby: Borgens Forlag. Oversættelse.

Parsloe, E. \& Wray, M. (2000). Coaching and Mentoring. Practical methods to improve learning, London: Kogan Page.

Stelter, R. (red.), (2002). Coaching - laring og udvikling,Virum: Dansk Psykologisk Forlag (Erhvervspsykologiserien). 